\title{
The Spouse's Nonbarrable Share: A Solution in Search of a Problem
}

\author{
Sheldon J. Plager
}

When a husband or wife wishes to leave his or her property to someone other than the surviving spouse, the state may feel compelled to intervene by requiring that the surviving spouse be permitted to share in the deceased's estate. The decision to accord the surviving spouse a share in the estate of the other regardless of the wishes of the decedent is attributable to a network of policy concerns which surround the protection of the family unit-the obligation of support, the presumed contribution of the survivor's family, and the state's interest in protection from the burden of indigents-as well as to policies favoring economy in transmission of property, equality of sexes, and fairness among beneficiaries. Giving effect to these concerns, however, frustrates such other policies as freedom of testamentary disposition, protection of creditors, and alienability of land, all of which militate against nonbarrable shares for the surviving spouse. ${ }^{1}$

Faced with this conflict, the eight-community property states ${ }^{2}$ and the civil law state of Louisiana protect the surviving spouse primarily by providing for a form of shared inter vivos ownership of marital property. Of the remaining forty-one states, only two leave the testator unfettered; ${ }^{3}$ thirty-nine states permit the surviving spouse to claim a share in the estate of the deceased spouse. ${ }^{4}$ The purpose of this study is

Sheldon J. Plager, Professor of Law, The University of Illinois, is a member of the Illinois and Florida bars. He received an A.B. degree in 1952 from the University of North Carolina, an LL.B. degree in 1958 from the University of Florida, and an LL.M. degree in 1961 from Columbia University. This article was written in partial fulfillment of the requirements for the degree of Doctor of the Science of Law in the Faculty of Law, Columbia University.

1 See Scoles, Conflict of Laws and Nonbarrable Interests in Administration of Decedents" Estates, 8 U. FLA. L. REV, 151, 156-61 (1955).

2 Arizona, California, Idaho, Nevada, New Mexico, Oklahoma, Texas, and Washington. Even in these states the surviving spouse may have some elective rights in the testamentary estate. See, e.g., Brown and Sherman, Elections To Take By Will: Some Practical Considerations, 23 CALIF. S.B.J. II (1948); Wren, The Widow's Election: Drafting and Tax Considerations in Community and Common Law States, 100 Trusts \& EsTATES 13, 108 (1961).

3 North and South Dakota.

4 Thirty-eight of the thirty-nine states and the District of Columbia have statutes purporting to give a surviving spouse-husband or wife or both-the right to choose between the deceased spouse's testamentary largess and a legislatively-decreed portion 
not to quarrel with policies underlying the decision to protect the surviving spouse; the question explored here is the soundness of the means by which the thirty-nine states have implemented that decision.

Although the specifics vary considerably, the thirty-nine states mentioned above have generally provided that the surviving spouse be entitled to a predetermined share, usually a third or a half, of the deceased's wealth. This portion is available regardless of the testator's wishes, regardless of the survivor's financial need, and regardless of how much or how little the survivor may have contributed to that wealth. This solution, generally known as the forced share, has one major advantage-it is relatively simple to administer. The probate court need only know the total value of the estate to which the forced share applies and the applicable proportion of the estate (as set out in the statute) to which the surviving spouse is entitled. There is usually no occasion for the taking of testimony about family relationships and history and no need for the application of judicial discretion. This simplicity, however, harbors the method's principal disadvantage-its total insensitivity to the surviving spouse's actual need, the contribution the survivor may have made to the estate, and the reason why the testator, who presumably knew his family situation as well as anyone, preferred his particular dispository plan.

An alternative is to provide a system of maintenance payments to the surviving spouse (and perhaps to other relatives) payable out of the decedent's estate. The amount of the payments would be keyed to the individual need of the survivor, the interests of persons who otherwise would be entitled to the deceased's property, the conduct of the survivor with relation to the deceased, the deceased's reasons for his dispositions, and the many other factors that might be relevant in a particular case. This is essentially the system established by the British Commonwealth decedent's family maintenance legislation. ${ }^{5}$

of the deceased's estate. These states are: Alabama, Alaska, Arkansas, Colorado, Connecticut, Delaware, Georgia, Florida, Hawaii, Illinois, Indiana, Iowa, Kansas, Kentucky, Maine, Maryland, Massachusetts, Michigan, Minnesota, Mississippi, Missouri, Montana, Nebraska, New Hampshire, New Jersey, New York, North Carolina, Ohio, Oregon, Pennsylvania, Rhode Island, Tennessee, Utah, Vermont, Virginia, West Virginia, Wisconsin, and Wyoming. South Carolina gives the surviving wife common-law dower. S.C. CodE ANN. $\S 19-153$ (1962). No choice is required by statute, although the husband by appropriate provision in his will can force the wife to choose between his testamentary provision and her dower share. See Note, Widow's Election Between Dower and Other Benefits, 9 S.C.L.Q. 277 (1957).

5 See Inheritance (Family Provision) Act, 1938, 1 \& 2 Geo. 6, c. 45; Family Protection Act, 1900, N.Z. Stat. 64 Vict. No. 20, as amended, N.Z. Stat. 11 Geo. 6, No. 60, § 15 (1947); Laufer, Flexible Restraints on Testamentary Freedom: A Report on Decedents Family Maintenance Legislation, 69 HARV. L. REv. 277 (1955). 
The advantage of this approach is its ability to shape the remedy to the facts and circumstances of each individual case. However, this flexibility is also its weakness. To do the job adequately requires that the court familiarize itself not only with the state of the deceased's finances, but with the whole range of his personal and family affairs. It further requires that the court exercise a high degree of judgment in balancing the various claims on the available assets-claims which can probably never be fully satisfied. This in turn means the court must be given a large measure of discretion, both to determine the protection afforded the spouse and the effect to be given to the testator's will.

Rather than argue on an a priori basis for one or the other of these alternatives, or for one of the variations that have been proposed from time to time, ${ }^{6}$ this study will examine the published data on patterns of testamentary behavior in an effort to determine the dimensions of the surviving spouse's problem. How widespread is the need for protection against disinheritance? On the whole, how does the surviving spouse fare in the competition for the deceased's favor? If the need is widespread and protection of the surviving spouse is a substantial activity of the courts, then economy of judicial effort alone may require that the forced share alternative be retained. Furthermore, if the impact of the forced share legislation is widespread, if many individuals and many estates are directly affected by it, a general reluctance to vest broad discretion in the courts in such matters may indicate the unlikelihood of political support for change. Under such circumstances, rough justice may be the best that can be hoped for.

On the other hand, if the need is great for the individual, but small in number of cases involved and in total individuals affected, rough justice may be poorer justice than the situation requires. We may be able to afford the luxury of individuation; to protect the surviving spouse who has genuine need, protect the testator's dispositive plan when there is no such need, and do it all without an undue burden on the courts. By knowing something of the extent of the problem, we should be able to better relate the need to the method best suited to meet it.

\section{The Available Data}

There are only a few published studies which explore on an organized basis the records of property transmission in a given jurisdiction

\footnotetext{
6 Macdonald, Fraud on the Widow's Share ch. 22 (1960) (hereinafter cited as MacDoNsLD); Haskell, The Power of Disinheritance: Proposal for Reform, 52 GEo. L.J. 499 (1964); Spies, Property Rights of the Surviving Spouse, 46 VA. L. REv. 157 (1960). See also Cahn, Restraints on Disinheritance, 85 U. PA. L. REv. 139 (1936) (one of the first proposals for reform).
} 
for a given period of time. The first American study, written by Richard R. Powell and Charles Looker of Columbia University Law School, appeared in 1930. This study was based upon New York probate court and tax department reports for the years 1914 through 1929; it does not appear to have involved the actual examination of individual probate files. ${ }^{8}$ (This study will hereafter be referred to as the New York Study.)

In 1950 a lawyer, J. $H$. Beuscher of the University of Wisconsin Law School, and an economist, Edward H. Ward of Montana State College, published a report of their examination of probate court files in 415 selected proceedings in the County Court of Dane County, Wisconsin, for decedents who died in 1929, 1934, 1939, 1941, and 1944. ${ }^{\circ}$ (This study is hereafter referred to as the Wisconsin Study.)

As of this writing, there has been only one other published study since the Wisconsin Study. In 1963, Allison Dunham of the University of Chicago Law School completed a study of the probate court records in ninety-seven estates for which probate proceedings were initiated in Cook County (Chicago), Illinois, in 1953, and seventy-three estates of decedents who died in Cook County in $1957 . .^{10}$ One of the aims of this study (hereafter the Chicago Study) was to test the degree of conformance between the legislatively decreed pattern of wealth distribution through intestate succession and the pattern actually employed by those decedents who utilized a will. As a result, the Chicago Study is especially useful as a source of data directly relating to patterns of wealth transmission between spouses.

In addition to these relatively comprehensive studies, there have been several papers published providing data on various aspects of testamentary behavior. Lawrence M. Friedman, of the University of Wisconsin Law School, published in 1964 an examination of 150 wills filed in Essex County, New Jersey, during the years 1850, 1875, and 1900.11 This analysis (referred to hereafter as the New Jersey Wills Study) was limited to the provisions of the testamentary instruments themselves and did not include other documents in the probate file. A candidate

7 Powell and Looker, Decedents' Estates, 30 Colum. L. REv. 919 (1930) [hereinafter cited as Powell \& Looker]. There was an English study published at about the same time, WEDGWOOD, THE ECONOMICS OF INHERITANCE (1929).

8 The statement was made that further studies, involving probate files, were in progress, $i d$. at $921 \mathrm{n} .8$, but none appears to have been published.

9 Ward and Beuscher, The Inheritance Process in Wisconsin, 1950 WL. L. REv. 393 [hereinafter cited as Ward \& Beuscher].

10 Dunham, The Method, Process and Frequency of Wealth Transmission at Death, 30 U. CHr. L. REv. 241 (1963) [hereinafter cited as Dunham].

11 Friedman, Patterns of Testation in the 19th Century: A Study of Essex County (New Jersey) Wills, 8 AM. J. LEGAL HIST. 34 (1964) [hereinafter cited as Friedman]. 
for a doctoral degree at the University of Kansas in 1956 surveyed the size and composition of probated estates in Kansas for the years 1940 and 1950.12 An occasional banker, doing graduate work at the Stonier Graduate School of Banking, surveyed local probate records or probate court reports for information on banking practices and incidentally collected data on testamentary behavior. ${ }^{13}$ A trade journal for trust men periodically published the results of a canvas of probate court clerks on the frequency of wills. ${ }^{14}$ The Federal Government regularly publishes a mass of statistics on fiduciary, gift, and estate tax returns. ${ }^{15}$

\section{The Traditional Function-Protection Against Disinherttance}

There is a glaring inconsistency in our law which compels a man to support his wife during his lifetime and permits him to leave her practically penniless at his death. . . . The average testator is just in his testamentary gifts to his dependents, but examples of injustice often occur. In one case brought to the attention of the Commission a man left his entire estate to his mistress .... In another case the wife had been the successful plaintiff in a separation action against her husband for cruelty .... . [She was subsequently disinherited.] This example of neglect is not uncommon in the Surrogate's Courts of the State..$^{16}$

By revealing such "blatant" inequities, the Commission to Investigate Defects in the Law of Estates, in its 1928 report to the New York Legislature, successfully argued for the enactment of legislation giving the surviving spouse in New York a choice between the legacy provided by the decedent spouse and an elaborately computed share of the decedent's estate. The statement in the report is taken almost verbatim from an address made by the chairman of the Commission, James A. Foley, before a Bar Association meeting early in 1928.17 Neither in his speech nor in his report did Surrogate Foley refer to any body of empirical data from which his conclusions as to the fre-

12 Pinet, Probated Estates in Kansas-1940 and 1950 (1956).

13 E.g., Miller, A Survey of Probate Records-Framework for Marketing Studies (Unpublished, Library of the American Bankers Assoc., N.Y., 1963); Smith, Hamilton County (Ohio) Probate Records (Unpublished, Library of the American Bankers Assoc., N.Y., 1941).

1499 Trusts \& Estates 414 (1960); 89 TRusts \& Estates 371 (1950).

15 E.g., U.S. Int. Rev. Serv., TrEasury DeP'T, Pub. No. 406, Fmuctary, Gift, and Estate TAX RETURNS-STATISTICS OF INCOME (1958).

16 Original Report of the Comm'n to Investigate Defects in the Laws of Estates 86 (1928), in Combined Reports of the [N.Y.] Decedent Estate Commission 18 (1933).

17 Combined Reports of the [N.Y.] Decedent Estate Commission 156 (1933). 
quency, and thus the social significance, of disinheritance were derived. The two cases cited were apparently cases in his own court. ${ }^{18}$

It is likely that Surrogate Foley was simply expressing the common understanding of mankind-or at least of lawyers. There are probably few attorneys today with any kind of an estate practice who have not read or heard about a case like Newman $v$. Dore ${ }^{19}$-an old man, married again, at odds with his new wife, on his death-bed instructs his attorney to find some way of cutting her out. The inter vivos trust of virtually all his assets executed three days before death in an effort to negate his wife's statutory rights in his estate made this testator's marital affairs a cause celebre in the law of estates and trusts and a spicy addition to the law school case books. It is not surprising then to find in much of the relevant literature an explicit assumption that when a choice is made by the surviving spouse in favor of the forced share it is necessitated by the unhappy relationship that existed between the spouses ${ }^{20}$ and an implicit assumption that the need of choice is widespread, and perhaps increasing.

\section{A. A Theory in Search of Support-Evaders and Divorcers}

An effort to support this general thesis with statistical data appears in W. D. Macdonald's exhaustive study of cases involving gratuitous inter vivos transfers in alleged evasion of the surviving spouse's statutory share. ${ }^{21}$ Macdonald begins with the assumption that the basic goal of the nonbarrable share is to provide economic assistance to the surviving spouse, typically the widow. ${ }^{22} \mathrm{He}$ acknowledges that thus far the total number of evasion cases is not large, ${ }^{23}$ but finds evidence that indicates to him that the number of actual evasions, if not the volume of litigation, is likely to increase. This conclusion is based on several factors.

First is the accelerating increase in "evasion" litigation itself. Mac-

18 Ibid. In his speech before the Bar Association, Surrogate Foley prefaced his "examples of injustice [which] often occur" with the statement: "In my experience as surrogate I have seen several." This statement was omitted from the Commission's report.

19275 N.Y. 371, 9 N.E.2d 966 (1937).

20 E.g., "Section 18 [the provision in the New York statutes giving the surviving spouse an election] is probably not needed or used when the couple has lived together in a normal, nonantagonistic relationship. . . . On balance, it would appear that Section 18 is called into play by the widow, who, as a wife, had a strained relationship with her husband." Garland, The "Non-Barrable" Share: Some Comments Regarding a Reappraisal, 32 ST. JoHN's L. REv. 218-19 (1958).

21 MACDONALD.

$22 I d$, at 6.

$23 \mathrm{Id}$. at $8 \mathrm{n} .9$. He suggests, however, that there may be a much larger number of unreported cases, such as those settled or otherwise not appealed. Ibid. 
donald states that since 1900 the evasion cases have increased more than fourfold, while the country's population has only slightly more than doubled. In addition, more than $50 \%$ of these cases have been litigated in the last twenty-five years. ${ }^{24}$ Dunham, in his Chicago Study, ${ }^{25}$ points out that Macdonald does not compare the increase in "evasion" litigation with the increase in testacy or estates in the same period nor with the increase in estates generally.

[Macdonald's] statistics show 17 cases for the decade ending in 1929 and 68 cases for the eight year period ending in 1958. If we assume they all arose in Cook County the increase is actually less than double for if the total wills in Cook County are taken as the base, the rate of such litigation increased from 6 per 10,000 wills to 10 per 10,000 wills. This would not appear alarming. ${ }^{26}$

Another factor Macdonald mentions in support of the proposition that there is a growing need for protection of the surviving spouse is an increase in family disharmony. ${ }^{27}$ Although recognizing that the extent of nationwide family disharmony is difficult to assess, he finds the rising American divorce rate significant, ${ }^{28}$ not in itself, but because it is accompanied by a high rate of remarriage. ${ }^{29}$ If either of the partners to the remarriage already has children, the situation is ripe for competing demands on the parent-spouse's estate; ${ }^{30}$ this would seem to be true whether the remarriage was successful or not.

While it is true that the divorce rate is higher now than it was 40 years ago (1.5 per 1,000 of population in 1923 compared to 2.2 in 1960), the present 2.2 rate is identical with the 1941 rate. ${ }^{31}$ Further, assuming that there is a rising divorce rate, it can be argued-and Macdonald recognizes the argument-that a high divorce rate might have the effect of reducing the number of spouses who die unmourned. If the disharmonious relationship is severed by divorce there is no surviving spouse

24 Id. at 7,8 .

25 Dunham 15 n.28.

28 Ibid.

27 Macdonald 10-15.

28 For information on the trends in marriage and divorce in the United States, see Metropolttan Life Ins. Co., Stat. Bull., Aug. 1949, Nov. 1949; U.S. Nat'l Office of Vital Stat., Dep't of Commerce, Summary of Marriage and Divorce Statistics: United States 1950 (1952). See generally Zimmerman, The Family of Tomorrow (1949).

29 See Metropolitan Life INs. Co., Stat. Bull., Mar. 1948, Jan. 1949, Apr. 1951. See also Glick, First Marriages and Remarriages, 14 AM. Socrol. REv. 726 (1949).

30 Macdonald estimates that children under 18 are involved in probably one half of all divorces and annulments. MacDonald 13.

31 Carter, Eight Myths About Divorce-and the Facts, N.Y. Times, May 3, 1964, § 6 (Magazine), p. 17. 
to disinherit. Of course, there are infinite degrees of disharmony and many rationalizations can be found by spouses for maintaining the marriage posture long after the desire has gone. Macdonald's preference for reading the divorce figures as supporting the need for protection against disinheritance may not be unreasonable, but the statistics are at best inconclusive.

\section{B. Patterns of Wealth Transmission at Death}

Even if the statistics on marital disharmony and inter vivos "evasions" were less than equivocal, they would be at best only indirect indicators of the extent to which there is a need for a forced share for protection of the surviving spouse. More to the point are the actual patterns of wealth transmission: By what methods do married people in fact dispose of their accumulated wealth at death and how much of it actually gets into the hands of the surviving spouse?

This question deals, however, with only one facet of the problemthe frequency of the need of protection when there is a married decedent with wealth. Consideration of the overall dimensions of the problem requires a look at additional data: How many people who die, die owning accumulated wealth; how many of this favored group are survived by spouses; of those who are, how much wealth is involved, particularly with respect to meeting the needs of the individual's dependents? Some of these questions will be touched on here, but the primary inquiry at this point will be focused on the question: Among those husbands or wives who in fact die leaving both a surviving spouse and sufficient wealth to quarrel over, how are these assets "passed on" and how does the surviving spouse fare in the competition for the decedent's favor?

The Available Alternatives for Transmission of WealthWill Substitutes

The husband or wife who wishes to transmit accumulated wealth at death may utilize various will substitutes, such as joint tenancy and bank accounts with survivorship, and thus leave no estate subject to succession proceedings; he may adopt the legislative scheme for allocation of his assets and die intestate; he may simply incorporate the legislative scheme into his will; he may provide by will for an allocation deviating in any number of ways from intestate distribution; or he may employ a combination of these.

Terminology may be tricky. In some of the literature the term "probate estate" is sometimes used to refer to those assets passing at death which are subject to judicial proceedings, regardless of whether the 
owner left a will or not. Technically, the term "probate" is limited to procedures involving estates of decedents dying testate, as distinguished from "administration" of intestate estates. For purposes of clarity, the admittedly more awkward term "succession" will be used to refer to the procedure of judicially administering assets of both testate and intestate decedents; the unqualified term "estate" or "succession estate" will be used to refer to the assets subject to such procedure. The term "probate" will be limited to its technical meaning in reference to estates involving a will.

a. Relationship of marital status to the necessity for succession proceedings. One of the analyses made in the Chicago Study ${ }^{32}$ of the 481 decedents in the 1957 sample was of the relationship between marital status and the existence of assets sufficient to warrant succession proceedings. The data indicated that the marital status of the decedent at the time of death appeared to be a significant factor in determining the presence of an estate.

The most significant marital category at time of death is "never married." One out of four of the estates in the sample came from this marital status, but decedents with a surviving spouse, on the other hand, had estates in only one of nine cases. ... [I]f a person has a surviving spouse at time of death ... he is less likely to have a probated estate than if he is a widow or widower or a single person who has never married. ${ }^{33}$

One conclusion that can be drawn from this is confirmation of what many husbands have long maintained-the old saw about two living as cheaply as one is pure feminine propaganda; marital status has a negative effect on the accumulation of wealth. However, studies of wealth distribution in the United States do not support this conclusion. Lampman, in his extensive study of the estimated 1,659,000 top wealth-holders in $1953^{34}$ - those individuals with $\$ 60,000$ or more of gross assets 35 -found that $72 \%$ were married, $16 \%$ were widowers or widows, $3 \%$ were divorced or separated, and $9 \%$ were unmarried. ${ }^{36}$ The percentage of individuals with wealth who were married was higher than for the population as a whole. ${ }^{37}$

32 Dunham.

33 Id. at 246.

34 Lampman, The Share of Top Wealth-holders in Nattonal Wealth (1962).

35 This group, comprising only $1 \%$ of the total population, held an estimated $\$ 309.2$ billion of gross assets, $30.2 \%$ of the total assets of the personal sector of the economy. Id. at 16.

36 Id. at 99.

37 Compare with the 1950 statistics for all persons 14 years old and over: married: 
An alternative interpretation of the Chicago Study findings is that a substantial number of married persons dispose of their assets through will substitutes. These substitutes include joint ownership of realty, survivorship bank accounts, and inter vivos trusts, as well as less formal devices such as gifts causa mortis, contracts to will, informal "escrow" arrangements, and Totten trusts. ${ }^{38}$

b. Sources of data on will substitutes. Unfortunately there is a great paucity of information on the frequency with which formal and informal will substitute mechanisms are utilized. In the main, two sources of reliable data are available. Certain of the transfers by will substitute are subject to estate or inheritance taxes by federal and state governments even though the transfers are not by will or intestate succession and therefore not part of the succession estate. While the filed tax returns provide the raw data, these data are limited to those estates of a size sufficient to warrant taxation. Furthermore, a copy of the federal estate tax return is not usually part of the estate file, and the federal government as a matter of policy does not permit general public inspection of individual returns, ${ }^{39}$ although periodic statistical analyses of large blocks of returns are published. 40 On the other hand, state inheritance tax returns are often part of the public record and, to the extent will substitutes are reported in them, the data may be obtained.

The other source of data is the occasional judicial proceeding undertaken for the purpose of providing record title to property passing outside the succession estate. For example, if husband and wife own real estate as joint tenants with survivorship (or tenancy by the entireties in jurisdictions recognizing that estate), the interest of the first to die automatically terminates at death and the survivor owns the entire property by operation of law. Unless the jurisdiction has a statutory procedure for establishing termination, the survivor typically establishes his ownership of record simply by filing an affidavit of death or a copy of the death certificate. ${ }^{41}$ Some states provide by statute for a

male $68 \%$, female $66.1 \%$; widowed: male $4.2 \%$, female $12.2 \%$; divorced: male $1.7 \%$, female $2.2 \%$; unmarried: male $26.2 \%$, female $19.6 \%$. Figures for March 1950 . U.S. BUREAU of the Census, Dep't of Commerce, Statistical Abstract of the Untted States 36, table 31 (1963).

$38 \mathrm{It}$ is of interest to note that the more recent casebooks on estates and trusts have begun to emphasize the significance of these "inter vivos" arrangements as alternatives for the transmission of wealth at death. See, e.g., Scoles \& HAlbach, Decedents' Estates and Trusts ch. 8 (1965); Ritchie, Alford, \& Efrland, Decedents' Estates and Trusts ch. IX (2d ed. 1961).

39 Congress has declared that tax returns constitute public records, INT. REv. CoDE of 1954 \& 6103(a), but the President, under the authority given him by Congress, ibid., has strictly limited public inspection. Treas. Regs. § 301.6103(a) (1963).

40 See, e.g., note 15 supra.

41 See 1 Flick, Abstract and Titre Practice $\S 464$ (1958). 
voluntary judicial proceeding which establishes the fact of death and terminates the joint tenancy. ${ }^{42}$ The court order when filed of record becomes prima facie evidence of the facts recited. A few states make such proceedings mandatory in order to establish of record the survivor's right to the property.43

c. Inheritance tax returns. In the Chicago Study, twelve of the 1957 estates were selected at random and their Illinois inheritance tax returns were analyzed for the purpose of determining the extent to which a deceased died with taxable assets that were not included within the succession estate. ${ }^{44}$

Of the twelve estates, five showed taxable assets all of which were included in the succession estate. Seven had some taxable assets not subject to succession proceedings. The total taxable assets of these twelve estates were $\$ 1,369,340.96$. Of this amount, the net taxable assets subject to succession proceedings were $\$ 1,259,570.30$; the total of taxable assets passing through will substitutes were $\$ 109,770.66$. Thus, only about $8 \%$ of the total taxable wealth transmitted at the death of these twelve decedents was transmitted through a will substitute; $92 \%$ passed by will or intestate succession.

Information was not given in the study as to how many of the twelve estates were testate and how many intestate. However, it was stated that $5.2 \%$ of the total assets subject to succession proceedings passed in the intestate estates, whereas $32.7 \%$ of the total assets transmitted through will substitutes was allocable to these same intestate decedents. ${ }^{45}$

It would be hazardous in the extreme to attempt to generalize on the basis of this information about the role of will substitutes in the transmission of property. First, the sample is extremely small. Second, not all assets transmitted by a will substitute are includable in the inheritance tax return. ${ }^{46}$ Finally, since the estates were not analyzed in

42 E.g., Cal. Prob. Code $\S 1170-75$; Mich. Comp. Laws $\S 702.116$ (1948).

43 E.g., Wis. Stat. ANN. $\$ \S 230.47,230.48$ (Supp. 1964); Minn. Stat. ANN. $\S 600.21$ (Supp. 1963). Whether the advantages of orderly procedures of record which result from required termination proceedings are worth the time and expense involved is open to question. In 1951, the California Legislature passed a bill, apparently with little notice, requiring judicial proceedings in order to terminate a joint tenancy; recording of the death certificate would no longer suffice. One of the state's newspapers launched a crusade against the bill, seemingly on the grounds that it was an unnecessary expense for the survivor and benefited only the Bar. The State Bar disclaimed ownership. The governor placed the matter before a special session of the legislature in 1952 and the bill was repealed. ABA Section of Real Property, Probate and Trust Law, 1952 ProceedINGS 36 [hereinafter cited as ProceEdings].

44 Dunham 264.

$45 \mathrm{Id}$. at 265.

46 Under Illinois law, for example, life insurance is not taxable on death, and therefore not includable in the return. 
terms of marital status, any conclusions regarding interspousal transmissions would be purely speculative.

d. Joint ownership of real property. There is some data available on the extent to which joint tenancy has been utilized as a will substitute. Of the seven estates in the Chicago Study in which the inheritance tax return listed some taxable assets not subject to succession proceedings, six had real estate held in joint tenancy and two had nonsuccession taxable property by reason of gifts in contemplation of death (one had both a contemplation of death gift and jointly held realty). ${ }^{47}$ Again, it does not appear in the study whether these jointly held assets passed to a surviving spouse.

Although Illinois does not have a statutory procedure for judicial termination of joint tenancy, Wisconsin does. In the Wisconsin Study, it was found that thirty-three of the 415 proceedings examined involved termination of a joint tenancy. ${ }^{48}$ This does not mean that these were all of the estates containing jointly held property; these were estates containing only jointly held property. The extent to which jointly held property was included in the other estates along with nonjointly held property was not shown. The property involved in each of these thirty-three cases was realty. The value was apparently not available in most of the cases. Although exact figures were not given, the statement was made that the surviving joint tenant was "practically always the wife or husband."49

In 1952 an American Bar Association committee ${ }^{50}$ sought information regarding joint ownership of real property in the United States by sending a questionnaire to a member of the bar in each of the states. ${ }^{.1}$ One of the questions was: "As between husband and wife, what percentage of real property titles are held in joint tenancy?" The question itself was somewhat ambiguous-did it purport to ask what percentage of real property owned either by a husband or wife was held in a co-tenancy which co-tenancy was a joint tenancy with the spouse or did it ask, if property was held in co-tenancy between husband and wife, what percentage was joint tenancy (or tenancy by the entireties) rather than tenancy in common? In any event, the responses ranged from Vermont, "very small percentage," to Florida, "at least half," to Illinois, Iowa, and Minnesota, indicating $80 \%$ or more. ${ }^{52}$

\footnotetext{
47 Dunham 264.

48 Ward \& Beuscher 397.

49 Ibid.

50 Committee on Community Property and Jointly Held Titles to Real Property, Section of Real Property, Probate and Trust Law.

51 See Procendings 33.

52 The Illinois respondent indicated $80 \%$ of homes, less of other properties.
} 
The Committee felt that "the significant development suggested by the answers is the increasing popularity and use of joint tenancy. No state reported a decrease in joint tenancy holdings, while in a number of states the increase in percentage of such holdings is marked."'53 Unfortunately the Committee's report did not give the data against which the percentages were compared, or the basis upon which the questionnaire's respondents made their judgments, or even the number (out of presumably forty-eight) who responded. ${ }^{54}$ On the whole, there is not sufficient information known about the method of obtaining the data and the sources utilized to warrant attaching much probative value to the findings.

e. Inter vivos trusts. While a few states require periodic reports to an appropriate governmental agency by trustees of charitable trusts, ${ }^{55}$ routine reporting to a public agency for record purposes is not usually required of a trustee of an inter vivos personal trust. The Uniform Trustees' Accounting Act, promulgated by the National Conference of Commissioners on Uniform State Laws in 1937, requires a trustee of an inter vivos trust ${ }^{56}$ to file with an appropriate public official, in addition to a copy of the trust instrument, a list of the names, addresses, and dates of birth of the known living beneficiaries, a description of any possible unborn or unascertained beneficiaries, and an inventory under oath of the trust property. ${ }^{57}$ The settlor, however, can remove his trust from the coverage of the act if he so desires. ${ }^{58}$ The act has been enacted in Kansas, Nevada, and New Mexico. ${ }^{59}$

In the absence of routine reporting procedures by trustees, ${ }^{60}$ the basic sources of data on inter vivos trusts are federal and, to a limited extent, state tax returns. If an inter vivos trust is irrevocable and the

53 Procendings 37.

54 "The response to this solicitation has been satisfactory . . . ProceEDINGs 33.

65 E.g., Cal. Gov't Code § 12586; Conn. Gen. Stat. ANn. § 45-82 (1960); N.C. Gen. Stat. $\S \S 36-19,20$ (Supp. 1963).

56 The language of the act is "non-testamentary trustee," defined as "a trustee serving under a trust created in this state otherwise than by a will, whether the trustee was appointed by the settlor or by a court or other authority." UNIFORM TRUsTEEs' Accounting Acr \& 1 .

57 Id. § 12.

68 Id. \& 15 .

59 KAN. Gen. Stat. ANN. § 59-1601 (1963); NEv. Rev. Stat. § 165.010 (Supp. 1956); N.M. StAT. ANN. § \$3-2-1 (1953).

60 A number of states require a trustee of a testamentary trust to file a periodic accounting with the Probate Court or other court of appropriate jurisdiction. The statutes are usually expressly limited to testamentary trusts. Florida, for example, provides that the statute may apply to inter vivos trusts, but only if the settlor specifically so provides in the trust instrument. For a collection of the statutes by states, see BOGERT, TRUSTS AND TRUSTEES §§ 965-69 (2d ed. 1962). 
settlor retains no substantial interest such as a right to income, the transfer into trust is in effect an outright gift of the beneficial interests. This type of transfer is not generally in the nature of a will substitute; the tax gatherer recognizes this, and if it is taxed at all it is taxed as a gift. ${ }^{61}$ If, however, the settlor retains substantial control over the trust assets until his death, such as a power to amend, alter, or revoke, he is typically using the trust as a will substitute. ${ }^{62}$ The tax gatherer recognizes this, and the trust assets are included as part of the settlor's estate passing at death. ${ }^{63}$ Thus, neither gift nor estate tax returns provide direct data on how much wealth is held at any given time in revocable trust funds created by living settlors.

In his study of top wealth-holders, Lampman estimated that of the probable $\$ 56$ billion held in personal trust funds in $1953,{ }^{64} 10 \%$, or about $\$ 6$ billion, was in revocable trusts created by persons who were still living. ${ }^{65}$ How much of this revocable trust wealth was transferred by married individuals and how much of it was given to spouses is not known. However, assuming that most of the total wealth held in trust was transferred into trust by individuals with assets over $\$ 60,000,{ }^{66}$ it is probable, in light of the fact that almost three-fourths of these individuals were married, ${ }^{67}$ that at least a similar proportion of those trusts that were revocable were created by married individuals. Using Lampman's figures, this would be about $\$ 4.5$ billion in revocable trusts created by married individuals. Furthermore, a married individual who creates a revocable trust will frequently be advised to make at least 50 per cent of the trust assets available to the surviving spouse in order to obtain the maximum marital deduction for estate tax purposes, ${ }^{68}$

61 See 1 Casner, Estate Planning, ch. 6 (3d ed. 1961). Of course, the trust assets may be includable for other reasons, for example because they were transferred in contemplation of death. INT. REv. CODE of 1954 § 2035; Casner, supra at 191.

62 The revocable inter vivos trust may also be used as a means of reallocating income for tax purposes, although there are elements of irrevocability involved. INT. REv. CODE OF $1954 \S 673$. On the use of the revocable inter vivos trust as a will substitute generally, see 1 Gasner, Estate Planning ch. 5 (3d ed. 1961).

63 INT. REv. CODE OF 1954 \& 2038.

64 Lampman considers $\$ 56$ billion "a conservative estimate." Lampman, op. cit. supra note 34, at 77. Powell, on the basis of the annual reports of the U.S. Comptroller of the Currency and other sources, estimated in 1954 that the total of assets held in private trusts by both corporate and individual trustees exceeds $\$ 85$ billion. He characterizes his conclusion as "the author's considered (but statistically unsupported) guess." 1 Powels, Real Property 20 (1954).

65 Lampman, op. cit. supra nate 34 , at 76.

68 Lampman, after analyzing a study of investment patterns of individuals and statistics of individual income tax returns with income frequency distribution from estates and trusts, concludes that "most of the amount in trusts and estates should be allocated to persons with estates over $\$ 60,000 . " I d$. at 78 .

67 Id. at 99.

68 An indication of the extent to which married decedents utilize the marital deduc- 
although there are some situations in which this might not be advantageous. ${ }^{60}$

f. Life insurance. Life insurance as a will substitute has the unique characteristic of changing in value by the fact of death. In 1960, life insurance in force in the United States had reached a new high of $\$ 586.4$ billion. $^{70}$ The bulk of this constituted ordinary ( $\$ 340.3$ billion) and group (\$175.4 billion) policies. ${ }^{71}$ Death benefit payments in 1960 amounted to a total of $\$ 3.3$ billion, of which $\$ 1.9$ billion was attributable to ordinary policies and $\$ 1.1$ billion to group policies. ${ }^{72}$

A national consumer survey conducted in 1960 found that, among the group sampled, ${ }^{73} 71 \%$ of all the men and $57 \%$ of all the women had some type of life insurance. ${ }^{74}$ If the individual was head of a family

tion can be seen from Fiduciary, Gift, and Estate Tax Returns-Statistics, of Income (1958), a statistical summary published by the U.S. Treasury Department of returns filed during the calendar year 1958. On the basis of the calculations outlined in the next two paragraphs of this note, it can be estimated that for the 17,110 married decedents for whom estate tax returns were filed, the total assets available after taxes for distribution to beneficiaries, including spouses, was $\$ 4.28$ billion. According to line 17 , table 2 at 58 , $\$ 1.64$ billion, or $38 \%$ of the calculated $\$ 4.28$ billion, qualified for the marital deduction, that is, was given to the surviving spouse outright or in such a manner as to be the equivalent of outright ownership (e.g., assets over which the surviving spouse has a general power of appointment. INT. REV. CODE OF 1954 \& 2056(b)(5)). This figure does not include interests passing to the surviving spouse that did not qualify for the marital deduction, such as income interests for life, nor does it reflect that part of any one estate in which the surviving spouse received more than 50 per cent of the adjusted gross estate.

Table 2 at page 58 presents for taxable estates by net estate classes, information on gross estate, deductions, specific exemption, taxable estate, and tax. Table 6 at page 62 presents information on the number of returns, net estate, marital status, age, and sex of decedents. The figures given for total taxable returns (line 22, table 6 at 62) were accumulated for all age groups of married decedents. This gave the total number of returns as 17,110 , and the total of net estate for married decedents before specific exemption as $\$ 2,926,995,000$.

Net estate is defined at page 53 as the taxable estate plus the specific exemption of $\$ 60,000$. In order to obtain the amount available for distribution after taxes, the entire amount of the marital deduction, $\$ 1,642,301,000$ (line 17, table 2 at 58) was added to the net estate, as the assets qualifying for the marital deduction are necessarily attributable in toto to the married decedents. To this figure was added $42 \%$ of the total charitable bequests of $\$ 509,364,000$ (line 18, table 2 at 58 ). (The $42 \%$ was arrived at by dividing $\$ 2.93$ billion of net assets attributable to married decedents by $\$ 6.97$ billion, the total net estate of all decedents.) This gave the figure of $\$ 4,783,000,000$, which was then reduced by $42 \%$ of the net tax liability (line 36 , table 2 at 58 ), or $\$ 498,000,000$. This gave the final figure, when rounded, of $\$ 4.28$ billion.

69 Lowndes \& Kramer, Federal Estate and Gift Taxes § 41.10 (2d ed. 1962).

70 InstrTute of LIfE Insurance, Life Insurance Fact Book: 1963, at 13 [hereinafter cited as FAcT Book]. This figure represents all life insurance (excluding reinsurance acquired) on residents of the United States, whether issued by United States or foreign companies.

71 Ibid.

72 Id. at 43.

73 The size of the sample was not given.

74 FACx BOOK 9 . 
in which there was a spouse, the percentage of insureds rose to 85 ; if the family unit included children under 18 , it rose still higher to $89 \%$.

By 1962 , the total of life insurance in force had risen to $\$ 675.9$ billion, of which $\$ 389$ billion was in ordinary policies, and $\$ 209$ billion in group policies. ${ }^{75}$ Death benefit payments in 1962 amounted to a total of $\$ 3.8$ billion, of which $\$ 2.1$ billion was attributable to ordinary policies, and $\$ 1.4$ billion to group policies. ${ }^{76}$

In an analysis of death benefit payments for the month of June, 1962 , it was found that, while women were the insureds in $18.6 \%$ of the ordinary life policies which matured, only $8.2 \%$ of the total of benefits paid were attributable to them. ${ }^{77}$ Thus, male insureds accounted for $81.4 \%$ of the policies and $91.8 \%$ of the coverage. On group policies, male insureds accounted for $87.8 \%$ of the policies and $91.5 \%$ of the coverage.

Of the total amount of death benefits paid during the month, $60.6 \%$ of the benefits from ordinary life policies and $75 \%$ from the group policies were paid to wives. ${ }^{78}$ While not all the male insureds were married, it is not unreasonable to assume ${ }^{79}$ that the percentage of

75 Id. at 13.

$76 \mathrm{Id}$. at 43 .

77 Id. at 41 .

78 Ibid.

79 This assumption is based on the following calculations: According to the Bureau of the Census, in March 1962 there were 43,019,000 married men out of a total male population of age 14 and over of 62,129,000. U.S. BUREAU OF THE CENSUS, DEP'T OF COMMERce, Statistical Abstract of the United States: 1963, table 31 at 36. Standardized for age, this meant $71.1 \%$ of the eligible male population in the United States was married. Applying this percentage to the percentage of death benefits attributable to male insureds the percentage of the total death benefits which can be allocated to married male insureds is $65.3 \%$ under ordinary life policies, and $64.9 \%$ under group policies. (This assumes that the percentage of death benefit payments can be allocated in proportion to the arithmetic groupings of marrieds and non-marrieds, a statistically unsupported proposition. The error introduced, however, is probably not large. The national consumer survey, supra note 74, reported that the mean amount of life insurance owned in 1960 by married heads of families (typically husbands) was $\$ 10,594$; the comparable figure for unrelated male individuals was $\$ 8,196$, a ratio of about 5 to 4 . When reduced to the approximately $65 \%$ of total benefits allocable to married male insureds, the potential discrepancy resulting from this assumption is less than $13 \%$ and probably considerably smaller.)

If $65.3 \%$ of the death benefits paid on ordinary life policies were attributable to married male insureds, and if wives received $60.6 \%$ of the total payments, wives were the beneficiaries of $93 \%$ of the benefits payable from ordinary life policies. By making the same calculation for group life policies, it is seen that wives received $115 \%$ of the death benefits attributable to group policy married male insureds, an obvious impossibility.

The error probably lies in assuming that the percentage of insured males who are married is the same as the percentage of married males generally. The 1960 consumer survey indicated that marital status had a direct bearing on life insurance coverageas stated above, it was estimated that $85 \%$ of married heads of families had life insurance, the highest percentage of any category in terms of family status. See note 74 supra 
male insureds who were married was as high as 85 , and thus the allocation of death benefit payments would attribute $77 \%$ of the total benefits paid to married male insureds. Wives then received $80 \%$ of the proceeds of the husbands' ordinary life policies and $97 \%$ of the group life policies.

The available data clearly suggest that to the extent life insurance is used as a will substitute by a married person, either to create an estate where none exists or to supplement an existing estate, the surviving spouse - whether husband ${ }^{80}$ or wife-is the object of favor and, in the case of the wife, is probably favored to the virtual exclusion of all others.

g. Summary. The statistics on the relationship of marital status to the necessity for succession proceedings clearly suggest that a substantial proportion of the wealth of a married individual is disposed of through a mechanism other than succession proceedings. Joint tenancy ownership between husband and wife seems to have widespread popularity and it appears likely that over half of some $\$ 4.5$ billion in revocable trusts eventually passes to the surviving spouse of the trustor. Of all the will substitutes, life insurance, with husbands providing $77 \%$ of the total benefits paid and wives receiving between $80 \%$ and $97 \%$ of these benefits, seems to be the most widely used and the one from which the surviving spouse most clearly benefits. It must be remembered, however, that the evidence regarding each of these mechanisms is fragmentary and probably insufficient to provide a basis for judging the proportion of the total assets of married decedents which is transmitted in this fashion.

\section{The Frequency of Wills}

The assets of an individual not disposed of during his lifetime or transmitted through a will substitute become at his death his succession estate. Unless the decedent leaves valid testamentary instructions,

and accompanying text. This is not the same as the percentage of insureds who are married, however. That figure probably lies somewhere between the $85 \%$ figure and the $70.1 \%$ of males who are married.

80 The same calculations made above can be made for death benefits attributable to female insureds and payable to husbands. For the month of June, 1962, 8.2\% of the death benefits paid under ordinary life policies were attributable to female insureds. Fact Boor 41. Of eligible females, $68.3 \%$ were married. Statistical ABstract, supra note 79, at 36. Putting these percentages together, it can be estimated that $5.6 \%$ of the death benefits attributable to female insureds were from married individuals. (But see note 79 supra for a potential source of error resulting from this extrapolation). Husbands received $2.7 \%$ of the total death benefits from ordinary life policies, or about $50 \%$ of the benefits attributable to married females. The figures for group life policies deviate by less than $1 \%$ from those for ordinary life policies. 
distribution of this estate will be in accordance with the statutory scheme provided for such situations. Of course, the distributees will get only what is left after the decedent's debts are paid, including the costs of a funeral probably conducted in a fashion to which the decedent was never accustomed during his lifetime. ${ }^{81}$

The theory behind the statutory scheme of distribution is presumably "that when a man dies without a will the law should try to provide so far as possible for the distribution of his estate in the manner he would most likely have given effect to himself if he had made a will."82 Under the early English law, at a time when land was the principle form of wealth, an owner of land was presumed to favor his blood relatives over his spouse. Neither husband nor wife was an heir of the other, ${ }^{83}$ although the spouse who survived was not left entirely propertyless. The widow's dower, and to some extent the widower's curtesy, provided a source of minimum support for the survivor's remaining years. ${ }^{84}$

Succession to the personalty of a married person was treated differently as a result of the split in jurisdiction between the law courts and the ecclesiastical courts. ${ }^{85}$ The surviving spouse, typically the widow, appears to have been given a share of the personalty at an early date. ${ }^{86}$ In 1670 the Statute of Distribution ${ }^{87}$ defined the widow's intestate

81 See MrtFord, The AmErican WAY of DeATH (1963). The dramatic presentation of the evidence in the Mitford volume on the high cost of dying finds striking support in the cold statistics of the Wisconsin Study, supra note 9. It was found that the proportion of the gross estate used to pay funeral expenses ran as high as an average of $53.3 \%$ in the group of intestate estates with a gross value of less than $\$ 2,000$. $I d$. at 407 . If the other costs of administration are first deducted, $i d$. at 404, and assuming no other creditors, the assets remaining for distribution in this group of estates are given on the average $79 \%$ to the undertaker, $21 \%$ to the surviving family. The percentage going to the undertakers declined steadily as the gross estate increased. For intestate estates over $\$ 50,000$ the percentage on the average was 0.7 . Ibid.

82 Parry, The LAw OF Succession 158 (2d ed. 1947), quoted in Dunham at 241. But see 6 POWELL, REAL PrOPERTY I 992 at 611 (1958): "The utilitarians, as exemplified by Bentham, regarded statutes on intestate succession as not justified as expressions of either 'natural law' or 'evolved human practices,' but as tools for the constructive generation of a desirable system, the details of which should conform to ethical valuestandards based on 'utility'."

832 POWELL, REAL Property If 176 (1950).

84 Id. at 127: "[Dower] was a reasonable product of a society in which most wealth consisted of land, and in which it was desired to provide at least a modest social security for surviving widows." On dower generally, see id. If 212; on curtesy generally, see $i d$. If 214.

85 See generally, 1 Holdsworth, History OF ENGLISH LAW 625 (1922); Atkinson, Brief History of English Testamentary Jurisdiction, 8 MO. L. REv. 107 (1943).

86 Plucknett, A Concise History of the Commion LAw 726 (5th ed. 1956).

8722 \& 23 Car. 2, c. 10. 
share in personalty as one-third if the husband left descendants, onehalf otherwise.

Almost two-thirds of the American jurisdictions, on the other hand, treat the surviving husband and surviving wife alike and provide the same pattern for distribution of both realty and personalty. ${ }^{88}$ The share given the surviving spouse generally ranges between one-third and one-half of the estate available for distribution, depending in some states on whether the other eligible takers are lineal descendants of the intestate. ${ }^{89}$ In the states which have not abolished the common law distinctions the surviving spouse typically takes a fractional share of the personalty and an interest in the realty that "bears traces of its origin in the laws of dower and curtesy." 90

Whenever an individual leaves testamentary instructions for disposition of his property he indicates a dissatisfaction with the statutory scheme for distribution. This raises two questions: first, how frequently do married individuals share this dissatisfaction; and second, what direction does their dissatisfaction take in terms of the share given the surviving spouse? The latter question is the subject of the next section. The former is the question explored here.

a. Wills for the living. In 1954, Columbia University Teachers College surveyed some 60,000 of its alumni concerning their willmaking habits. In addition, the survey questionnaire was sent to about 6,000 alumni of the schools of engineering, journalism, pharmacy, and law.

The full results of the survey were apparently never published, and, unfortunately, the statistical analysis of the survey is no longer extant. ${ }^{91}$ However, several brief summaries of portions of the study were reported in published sources; ${ }^{22}$ on the basis of these reports plus information supplied by Teachers College ${ }^{93}$ it is possible to reconstruct an overall picture of the data..$^{94}$

After eliciting various personal data such as age, occupation, marital status, and income bracket, the questionnaire asked, "do you have a will? Yes ( ) No ( )." The tabulated responses were:

886 Powell, Real Property 624 n.93 (1958) lists the jurisdictions and cites the relevant statutes.

89 Ibid.

$90 \mathrm{Id}$. at 625 .

91 Letter from Mr. Abel A. Hanson, Gen'l Secretary, Columbia University Teachers College, to the author, April 2, 1964. Mr. Hanson was chairman of the ad hoc committee reporting on the relationship of estate planning to college development programs.

9294 Trusts \& Estates 282 (1955); 6 Powell, Real Property If 995 at 606 (1958).

93 See letter, supra note 91 .

94 The response to the questionnaire was astonishingly high-nearly 45,000 returns were reportedly received within three weeks of initial mailing. Ibid. 
Occupation

\section{Lawyers}

Engineers

Teachers

Journalists

Pharmacists

All categories
Per cent reporting having a will

\begin{tabular}{ll}
\hline Lawyers & 71 \\
Engineers & 54 \\
Teachers & 53 \\
Journalists & 49 \\
Pharmacists & 31 \\
All categories & 51 \\
\hline
\end{tabular}

Some detail on the lawyer category is known. Ninety-two and eighttenths per cent of the lawyers replying were men; $77.5 \%$ were married, $85.6 \%$ had dependents; the median age group was 43; the two largest income groups earned up to $\$ 9,999$ and $\$ 19,999$ a year respectively, with a few making under $\$ 5,000$ and one over $\$ 50,000$. Eighty-one per cent of the lawyers who reported having a will gave everything to one or more members of their surviving family. ${ }^{95}$

It must be recognized that the group surveyed by the Teachers College was a select group of professionals, graduates of one of the leading educational institutions in the country. Their chances of accumulating sufficient assets during their lifetime to comprise an estate at death would appear to be substantially better than the average of American adults; therefore their concern with making appropriate testamentary disposition should be materially greater.

This suggestion finds support in a reported sampling survey on willmaking made by the Opinion Research Corporation shortly before $1949 .{ }^{96}$ On the basis of their survey, the projection was made that of the total voting age population of the United States, only $19 \%$ had wills, whereas among the top one-third economically, $41 \%$ had wills.

b. Wills for the dead. Table 1 presents, chronologically, data from the various published studies on the proportion of wills to intestacies in estates under judicial administration.

The 1930 New York Study ${ }^{97}$ figures indicate that, while there was a steady increase over the sixteen year period in the proportion of adult decedents leaving wills which were probated, ${ }^{98}$ the proportion of wills to intestacies remained more or less constant. The Wisconsin Study, ${ }^{99}$ on the other hand, found a substantially higher percentage of wills generally but a declining proportion of testacy. The authors of the

9594 Trusts \& Estates 282 (1955).

96 Reported in 6 Poweir, Real Property 606 n.2 (1958).

o7 Powell \& Looker 923-24.

98 E.g., New York County: 1915-8.2\%, 1921-11.4\%, 1929-12.5\%. Id. at 924-26.

99 Ward \& Beuscher. 
TABLE 1

RATIO OF WILLS to INTESTACTES 100

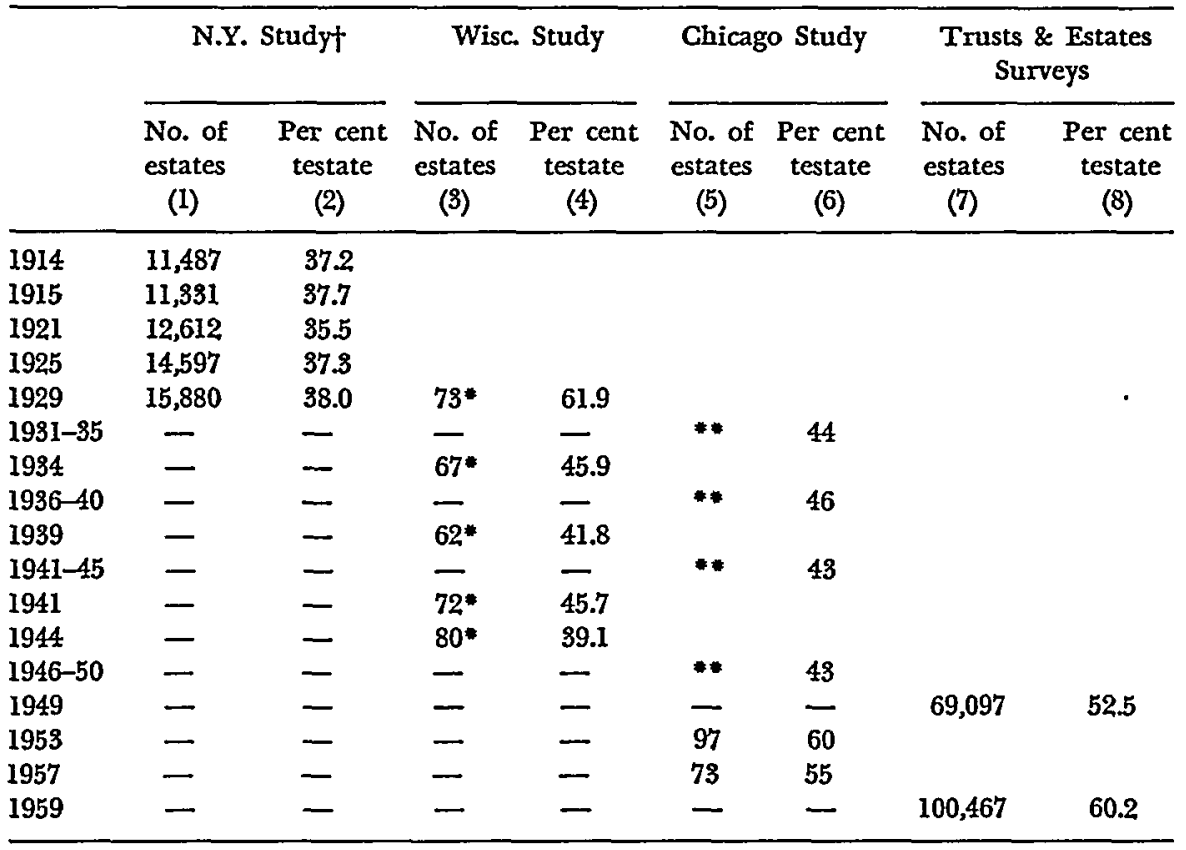

- Approximate, see explanation in source note, note 97.

* Unknown, but probably large. See text discussion.

+ Selected years only. See source note, note 97 .

Wisconsin Study found "no obvious explanation" for the trend.101 The Chicago Study ${ }^{102}$ provided data on wills versus intestacies for the period 1931-1950 broken down into five-year increments, as well as for the sampled years of 1953 and 1957. It is not clear from the study how many estates were involved in the five-year groupings nor what

100 Columns 1 and 2 are derived from Powell \& Looker, Decedent's Estates, 30 Colum. L. REv. 919, 924 (1930). Five of the 16 years covered there were selected at random and presented here. The figures shown result from combining the statistics for both New York and Kings Counties.

Column 4 is derived from Ward \& Beuscher, The Inheritance Process in Wisconsin, 1950 Wis. L. REv. 393, 412. Column 3 is a reconstruction obtained by applying column 4 to the number of estates with wills for each of the years involved. These figures were obtained from id. at 415-16, and were, in chronological order, 45, 31, 26, 33, and 31 . However, the figure of 166 total testate estates thus obtained does not agree with the statement that there were 172 testate estates in the sample. Id. at 393. The source of the discrepancy is not readily apparent. See also id. at 414, giving a third figure, 163, as the total wills for all years.

Columns 5 and 6 are from Dunham 244.

Columns 7 and 8: 1949 data are from 89 Trusts \& EsTATES 371 (1950); 1959 data from

99 Trusts \& Estates 414 (1960).

101 Id. at 412 .

102 Dunham. 
the source was for the percentage figures given. Apparently the figures were based upon a survey of all succession proceedings held in Cook County during the stated years, a number undoubtedly in the thousands. ${ }^{103}$

It can be seen that the statistics based on large-scale data showed a generally constant proportion of wills to intestate proceedings. The New York Study for a sixteen year period (1914-1929) and the Chicago Study for a twenty year period (1931-1950) showed an apparent variation of 3 percentage points or less. On the other hand, the Wisconsin Study, on the basis of a sample of 367 estates, ${ }^{104}$ showed a range in selected years over a fifteen year period (1929-1944) of almost 23 percentage points. The Chicago Study's two sampled years (1953 and 1957), involving 170 estates, had a range of only 5 percentage points, but varied from the twenty year period figures by 17 percentage points.

In the light of the self-evident proposition that the figures derived from large-scale data are more reliable than those derived through sampling techniques, it appears that the ratio of wills to intestacies did not vary markedly over a given period of time, even as long as twenty years.

Comparing the two groups of large-scale data, it can be seen that the New York Study during the period 1914-1929 showed an average of $37 \%$ testacies, while the Chicago Study during the period 1931-1950 showed an average of about $45 \%$. Does this indicate a general upward trend in the employment of wills or is this explainable on the basis of geographic-cultural differences? The evidence indicates both hypotheses may have validity.

The geographic-cultural explanation gains support in the findings of the two surveys by Trusts and Estates. In the 1949 survey, covering 30 counties in 16 states, the ratio of testacies ranged from a low of $32 \%$ (Bronx County, New York and Vandenburgh County, Indiana) to a high of $74 \%$ (Travis County, Texas). ${ }^{105}$ Ten years later, in a survey covering 53 counties in 31 states, the high percentage was (again in Travis County, Texas) $89 \%$ and the low was $27 \%$ (Washington County, Vermont). ${ }^{106}$

Geographical distribution alone showed little consistency in pattern. There were substantial percentage differences between metropolitan

103 In 1949 the figure was 7,173. 89 Trusts \& Estates 371 (1950) [hereinafter cited as 1949 Survey].

104 Ward \& Beuscher 393.

10589 TRUSTS \& ESTATES 371 (1950). The figures were based on statistics provided by the clerks of the various courts with probate jurisdiction.

10699 Trusts \& ESTATES 414 (1960) [hereinafter cited as 1959 Survey]. 
areas within a single state. ${ }^{107}$ Even regional characteristics did not seem to control. ${ }^{108}$ On the other hand, population statistics tended to establish a discernible pattern, at least at the extremes. Among the counties surveyed, the four largest, each with a population in excess of 1.5 million, had an overall ratio of wills to intestacies of $63 \% .{ }^{109}$ The four smallest, with an individual population less than 61,000 , had an overall ratio of $34 \% .{ }^{110}$ Undoubtedly wealth and income distribution as well as other cultural factors contribute to the overall pattern; the evidence is clear, as developed below, that these are significant operative variables in the individual's decision to use a will.

The hypothesis that there is an increasing ratio of wills to intestacies is supported by a comparison of the overall percentages of the two Trusts and Estates surveys. The two surveys were ten years apart and showed a 7.7 percentage point increase in the use of wills-from 52.5 in 1949 to 60.2 in 1959. This contrasts sharply with the almost unchanging percentages found in the sixteen and twenty year New York and Chicago studies. The results of the Trusts and Estates surveys cannot be attributed to the expanded size of the 1959 survey. If the 30 counties used in the 1949 survey are separated out of the 1959 survey they show almost the identical ratio- $60.4 \%$ - found in the overall 1959 group. ${ }^{111}$

Furthermore, both the 1949 and 1959 surveys fortuitously included the counties involved in the three other studies in Table 1-Cook (Chicago), Dane (Wisconsin), and New York (New York). Tables 2, 3 , and 4 present a composite picture of each of these counties, utilizing the survey statistics and those of the three studies, as well as one additional study identified in the source note to Table 4. The tables clearly indicate an accelerating trend within each given area toward the use of testamentary instruments.

c. Marital status as a factor in the frequency of wills. How do the general patterns developed in the preceding section correspond with

107 E.g., Los Angeles County, 66\%; San Francisco County, 37\%. 1959 Survey.

108 E.g., two of the top counties percentage-wise were Fulton, Georgia, $78 \%$, and Westchester, New York, 75\%. Among the lowest were Laramie, Wyoming, 33\%, and Merrimack, New Hampshire, 30\%. 1959 Survey.

109 These counties and their 1960 populations were: Los Angeles (California), 6,038,771; Cook (Illinois), 5,129,725; Philadelphia (Pennsylvania), 2,002,512; New York (New York), $1,698,281$. The population figures given in the 1959 Survey were based on 1950 census statistics. The 1960 figures are from U.S. Bureau of the Census, Dep'T of Commerce County and City Data Book 1962, table 2.

110 These counties and their 1960 populations were: Laramie (Wyoming), 60,149; Pennington (South Dakota), 58,195; Fairbanks (elec. distr.) (Alaska), 43,412; Washington (Vermont), 42,860. Ibid.

1111959 Survey. 
TABLE 2

Ratio of Wills to Estates-Cook County (Chrcago), Illinois

\begin{tabular}{clcc}
\hline Line & Year & $\begin{array}{c}\text { No. of } \\
\text { Estates }\end{array}$ & $\begin{array}{c}\text { Per cent } \\
\text { Testate }\end{array}$ \\
\hline 1 & $1931-35$ & & 44 \\
2 & $1936-40$ & $*$ & 46 \\
3 & $1941-45$ & $*$ & 43 \\
4 & $1946-50$ & 7,173 & 43 \\
5 & 1949 & 97 & 44 \\
6 & 1953 & 73 & 60 \\
7 & 1957 & 12,541 & 65 \\
8 & 1959 & & 68 \\
\hline
\end{tabular}

Source: See note 112.

- Unknown, but probably large. See text discussion.

TABLE 3

Ratio of Wilts to Estates-Dane County (Madison), Wisconsin

\begin{tabular}{cccc}
\hline Line & Year & $\begin{array}{c}\text { No. of } \\
\text { Estates }\end{array}$ & $\begin{array}{c}\text { Per cent } \\
\text { Testate }\end{array}$ \\
\hline 1 & 1929 & $73^{*}$ & $61.9 \dagger$ \\
2 & 1934 & $67^{*}$ & $45.9 \dagger$ \\
3 & 1939 & $62^{*}$ & $41.8 \dagger$ \\
4 & 1941 & $72^{*}$ & $45.7 \dagger$ \\
5 & 1944 & $80^{*}$ & $39.1 \dagger$ \\
6 & 1949 & 554 & 55.0 \\
7 & 1959 & 583 & 66.0 \\
\hline
\end{tabular}

Source: See note 113.

* Approximate. See explanation in source note to Table 1, supra note 97.

$\dagger$ For estimate of reliability of these figures, see text discussion.

TABLE 4

Ratio of Wills to Estates-New YoRk County (MANHattan), N.Y.

\begin{tabular}{clcc}
\hline Line & Year & $\begin{array}{c}\text { No. of } \\
\text { Estates }\end{array}$ & $\begin{array}{c}\text { Per cent } \\
\text { Testate }\end{array}$ \\
\hline 1 & 1914 & 6,852 & 32 \\
2 & 1915 & 6,613 & 32 \\
3 & 1921 & 7,033 & 33 \\
4 & 1925 & 7,846 & 36 \\
5 & 1929 & 7,847 & 38 \\
6 & 1949 & 6,665 & 45 \\
7 & $1955-56^{*}$ & 6,824 & 46 \\
8 & 1959 & 6,892 & 55 \\
\hline
\end{tabular}

Source: See note 114 .

* July 1 through June 30.

112 Lines $1-4,6$, and 7 are from table 1; line 5 is from the 1949 Survey; line 8 is from the 1959 Survey.

113 Lines 1-5 are from table 1; line 6 is from the 1949 Survey; line 7 is from the 1959 Survey.

114 Lines 1-5 are derived from Powell \& Looker 923; line 6 is from the 1949 Survey; line 7 is from Second Annual Report 2 Judicial ConfERENcE of THE STATE OF NEW YORK ANN. REP., LEGIS. Doc. No. 88, at 214 (1957); line 8 is from the 1959 Survey. 
the behavior of decedents who were married at the time of death? Regrettably, only the Chicago Study provided data bearing on this precise point. The 73 estates in the 1957 sample were analyzed in terms of the decedents' marital status at death. ${ }^{115}$ The percentage testate of all estates in each category was: ${ }^{116}$

Married
Widowed
Divorced
Never Married

Overall
Per cent

54

59

50

54

54.6

When the 1957 sample was combined with the 1953 sample ${ }^{117}$ and the estates were viewed in terms of categories of survivors, the percentage testate of all estates was: 118

$\begin{array}{ll}\text { Spouse and children surviving } & 50 \\ \text { Spouse without children } & 46 \\ \text { Children without spouse } & 69 \\ \text { Neither spouse nor children } & \\ \text { but brothers or sisters } & 54 \\ \text { Other relatives survive } & 67\end{array}$

On the basis of these figures, marital status by itself does not seem to be a controlling factor in influencing the decision as to whether to die testate or intestate. Obviously the data are not broad enough to support any categorical conclusions; additional information on the point needs to be gathered.

d. Size of estate as a factor in the frequency of wills. One of the pleasant uses of statistics is to confirm what we have always believed. Common experience among the estate planning trade suggests that the more wealth an individual has, the higher the probability that he will be familiar with the use of legal instruments to define and regulate property interests and will want to use such an instrument in transmitting his wealth at death. Striking confirmation of this belief is found in the data provided in the Chicago and Wisconsin studies and presented graphically in Chart 1 .

116 The table from which the percentages were taken, Dunham 247, does not identify the source as the 1957 sample. However, the data given in the table on the number of decedents in the sample clearly indicates that this was the source, and not the combined 1953 and 1957 data.

110 Ibid.

117 Again, the table from which the percentages were taken, Dunham 252, does not identify the source, but the context in which the data is presented indicates that it is probably the combined samples.

118 Ibid. 
The Chicago Study presented data for Cook County in 1950 showing the percentage testate of all estates in six valuation brackets ranging from "below $\$ 5,000$ " to " $\$ 100,000$ and over." 119 The total number of estates from which the data were developed is not given; presumably the figures were based on the complete data for that year, which would probably mean in excess of 7,000 estates. ${ }^{120}$

Chart 1. Percentage Testate of All Estates by Value of Estate

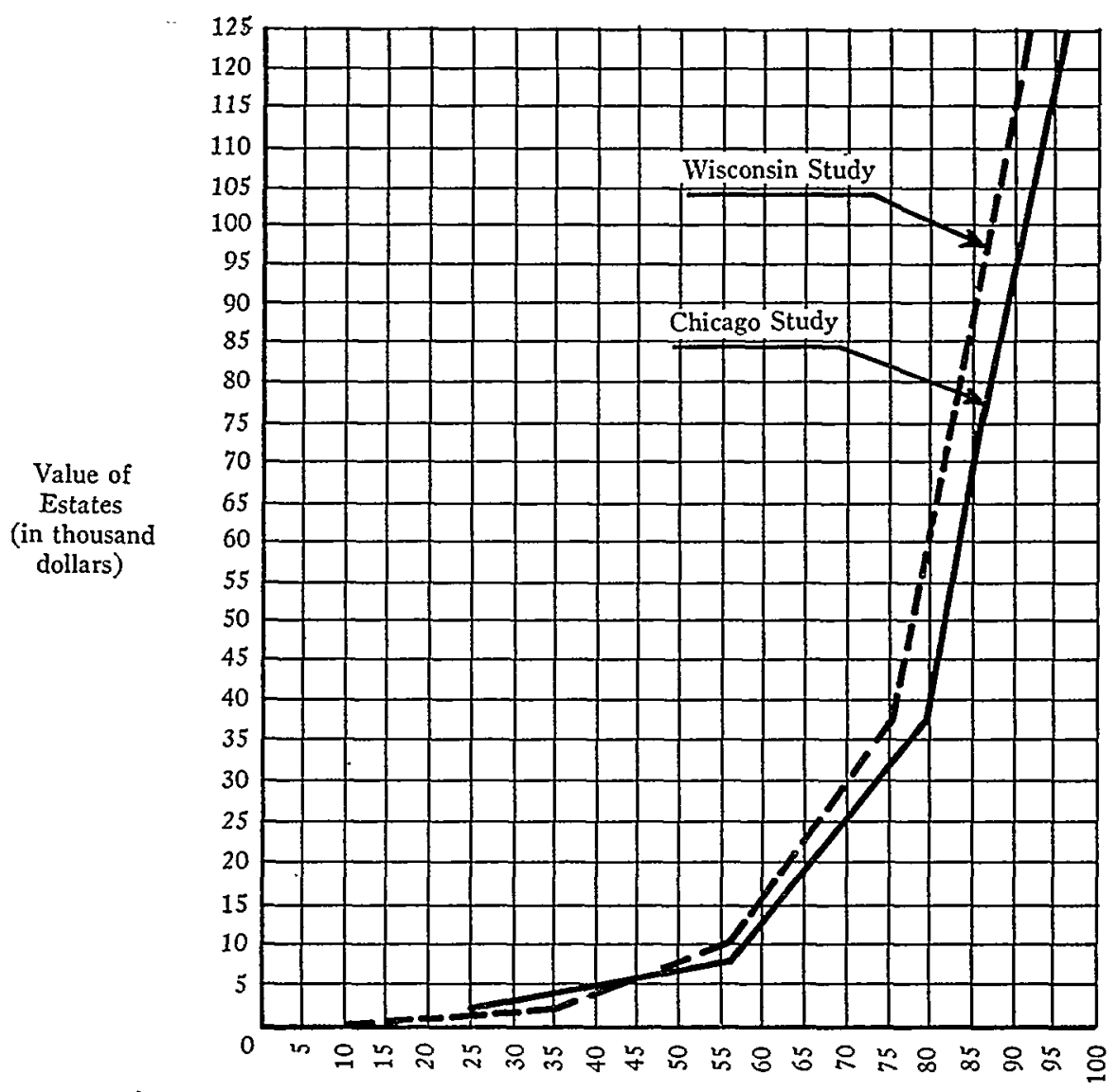

Percentage Testate of All Estates

Source: See note 123.

119 Dunham 250. The brackets and percentage testate for each bracket were: Below $\$ 5,000,25 \% ; \$ 5,000-\$ 9,999,56 \% ; \$ 10,000-\$ 24,999,63 \% ; \$ 25,000-\$ 49,999,79 \% ; \$ 50,000-$ $\$ 99,999,86 \% ; \$ 100,000$ and over, $96 \%$.

120 "Tables 7 and 8 [are] taken from the last complete data for Cook County in 1950 ... Id. at 249. In 1949, Cook County reported 7,173 estates filed. 1949 Survey. 
The Wisconsin Study presented data for each of the five years studied between 1929 and 1944 and the combined data for all five years. ${ }^{121}$ Chart 1 was based on the combined data. The data were given in terms of six valuation brackets, although the brackets differed somewhat from those in the Chicago Study. ${ }^{122}$ The basis for the data was the 367 estates in the Wisconsin Study sample. While there was some variation in the percentages for the individual years, probably due to the smallness of the sample, the remarkably close conformance of the overall percentages in the two studies is apparent. ${ }^{123}$

Chart I clearly illustrates that probably the most significant variable in determining whether a decedent with wealth dies testate or intestate is the amount of wealth he has accumulated. If net worth exceeds $\$ 35,000$ to $\$ 40,000$, the chances are that three out of every four decedents will utilize a dispositive instrument; if net worth is large enough to require filing a federal estate tax return, there will be a will in better than four out of five cases.

The chart does not tell us anything directly about the total amount of wealth passing by will as compared to that passing through intestacy. However, by combining the evidence indicating that something better than $50 \%$ of all estates are testate with the fact that an extraordinarily high percentage of the larger estates are included in the testate group, the clear implication is that a high percentage of the total wealth transmitted at death passes by will. Thus, it is not surprising that the Chicago Study reported:

From the estates in the sample years 1953 and 1957 as to which sufficient information was available to obtain a total of the values stated for probate, it would appear that 90 per cent of the wealth transmitted at death through probate

121 Ward \& Beuscher 412.

122 The brackets (in thousands) and percentage testate for each bracket were (all years combined): $0,10.7 \% ; 0-5,35.6 \% ; 5-15,55.6 \% ; 15-25,52.4 \% ; 25-50,75.0 \% ; 50-200,92.3 \%$. Ibid.

123 The Chicago Study curve is derived from Dunham 250. The graph was constructed by locating the percentage figures midway between the valuation figures in each bracket. For bracket and percentage figures, see note 119 supra. The location of the percentage figure for " $\$ 100,000$ and over" was arbitrarily placed at the top of the valuation index on the graph, representing a figure of $\$ 125,000$.

The Wisconsin Study curve is derived from Ward \& Buescher 412. The graph was constructed in the same manner as the Chicago Study curve. For brackets and percentage figures, see note 122 supra. The percentage figure for the $15-25$ bracket plotted substantially off the curve developed from the other figures. The reason for this is that in the sample year 1934 this bracket showed a percentage testate of 0.0 (the other years ranged between $25 \%$ and $90 \%$ ). Ibid. This distortion was deemed to be due to the small size of the sample, and therefore the percentage figure for this bracket was not used in constructing the curve. 
was transmitted in testate estates. $\$ 4,031,458$ was transmitted by will as against $\$ 441,680$ by intestacy..$^{124}$

\section{The Spouse's Share by Will}

When a married individual elects to dispose of his or her assets at death by will rather than through the legislature's intestate plan, how does the surviving spouse fare in the competition for the testator's blessing? Do the patterns of testation indicate that the survivor's interest is typically limited to support for the remaining years; or is means of support something the testator is willing to leave to the survivor to work out on his or her own; or is the bulk of married persons' wealth left outright to the spouse, presumably on the theory that in the long run this is the best way to care for the objects of the testator's bounty? Of course, more than the testator's attitude about his family and his marital obligations will enter into the decision. In high valuation estates, estate tax consequences will loom large and may affect both the size of the share going to the surviving spouse and the restrictions placed on the share. Even so, there remain discernible differences in pattern between dispositions designed to protect the spouse within the context of sound tax planning and dispositions designed to disinherit.

In analyzing probate records in terms of testate versus intestate estates, the New York Study limited itself to the question of whether there was a will and specifically omitted compiling data on the frequency and ways in which testamentary dispositions differed from the intestacy law. ${ }^{125}$ However, both the Chicago ${ }^{126}$ and Wisconsin ${ }^{127}$ studies did include some analysis of dispositive patterns, and the New Jersey Wills Study ${ }^{128}$ also included some useful data.

a. The spouse's share: life estate versus an interest in fee. Friedman, in his study of 19th century wills in New Jersey, noted a marked trend, over the course of the century, away from testamentary dispositions creating limited interests (trusts and life estates) and toward dispositions creating outright interests. ${ }^{129}$ This trend was directly re-

124 Dunham. In 1949, the president of one of the major trust companies in Hawaii estimated that "approximately $85 \%$ in dollar value of the estates of deceased persons [in Hawaii] are devised and bequeathed by valid wills." Steadman, The Trust Business in Hawaii, Trust Bull., Nov., 1949, pp. 14, 18. No indication was given as to the basis for the estimate.

125 See Powell \& Looker 921 n.8.

128 Dunham.

$12 \pi$ Ward \& Buescher.

128 Friedman.

$129 \mathrm{Id}$. at 41. 
flected in the types of dispositions made by testators for their surviving spouses. ${ }^{130}$

In 1850 the number of wills which made at least some nonfee disposition for the widow was more than twice that of wills which made fee dispositions only. In 1875 non-fee dispositions had only a slight margin (23 to 19 ), and by 1900 fee dispositions had a substantial majority (17 to 10$)$. Thus the earlier the will in Essex County, the more likely it was to make non-fee gifts to the wife. (Gifts to husbands-which occurred only in 1875 and 1900 -were usually gifts outright. $)^{131}$

As the pattern toward the latter part of the century shifted away from the life estate and toward fee dispositions, the surviving spouse benefited. "Fee-disposition wills frequently left everything to the surviving spouse; it is likely that some of these wills were drafted for that very reason."132 Friedman concluded that "among those who executed wills, there was a marked tendency to increase the share of the surviving spouse."133

The Wisconsin Study remarks that "during the years under examination, life estates created by will (trust and non-trust) ... comprised an average of $24 \%$ of the testate estates." 134 This probably means that $24 \%$ of the testate estates contained wills having one or more provisions creating life estates. While there was considerable fluctuation among the five years studied, and "no particular trend seems apparent,"135 the overall percentage figure is consistent with the downward trend noted in the New Jersey Study. ${ }^{136}$

With respect to life estates and the surviving spouse, the Wisconsin Study reports:

As was to be expected, life estates were created primarily for the benefit of the deceased's spouse $(80 \%)$. Widows were the beneficiaries in $75 \%$ of the life estates created by trust, and they were the life tenants in $60.7 \%$ of the other life estates. Surviving husbands became life tenants in $17.8 \%$ of the cases. In the remainder of the cases, life tenancies are distributed among various relatives. ${ }^{137}$.

130 Friedman's 150 testators consisted of 112 males and 38 females. $I d$. at 36 .

131 Id. at $42-43$.

132 Id. at 44.

$133 \mathrm{Id}$. at 53.

134 Ward \& Beuscher 418.

135 Ibid.

136 Friedman's figures give percentages of: $1850-68 \% ; 1875-55 \% ; 1900-37 \%$. Friedman 43.

137 Ward \& Beuscher 419. 
b. The spouse's share: competition with other survivors. The New Jersey Study reveals that in each of the years studied a substantial number of the wills examined made no provision at all for a surviving spouse. ${ }^{138}$ In 1850,11 of the 30 wills, or $37 \%$, had no provision for a spouse; in 1875, it was 18 out of 60 , or $30 \%$; while in 1900 the figures were 33 out of 60 , or $55 \%$. Does this mean that there was a high incidence of marital disinheritance, or does it mean, as Friedman contends in regard to the 1900 figures, that "clearly most of these testators were unmarried or widowed"?139 Unfortunately, without further data, no supportable conclusions can be drawn.

The Wisconsin Study ${ }^{140}$ included an analysis of the extent to which the wills deviated from the distribution provided by law. Table 5 reproduces this information for the combined five years studied.

TABLE 5

Deviations from Distribution Provided by LAW-Wisconsin Study141

Distribution identical with that provided by law

No heirs omitted, distribution almost identicala

No heirs omitted, but substantial variance in distribution

One or more heirs omitted

Totals
No. Wills Per cent

\begin{tabular}{rr}
14 & 8.6 \\
19 & 11.6 \\
70 & 42.0 \\
61 & 37.4 \\
\hline 164 & 99.6
\end{tabular}

a A distribution "almost identical" with that provided by law is of course a matter of judgment on which there might not be complete agreement between several observers. For instance the devise of a life estate in land was not deemed "almost identical" with a widow's fee simple dower right, but the devise of a life estate to a widow with full power of appointment was.

Source: See note 141.

The data does not provide direct information on the extent to which a surviving spouse was favored or disfavored in those cases in which there was substantial deviation or in which heirs were entirely omitted. However, as part of the explanation of the category in the table "one or more heirs omitted," the Study stated:

The table shows that in $37.4 \%$ of all wills one or more heirs is not provided for. But in almost $40 \%$ of these cases the will devised all or practically all of the estate to the surviving spouse-a not unnatural distribution. As a matter of fact, practically all testators transferred their property "within the family."142

138 Friedman 43.

$139 \mathrm{Id}$. at 46 .

140 Ward \& Beuscher.

141 Taken from Ward of Beuscher 44. The explanatory quotation is from id. at 413.

142 Ibid. 
The Chicago Study ${ }^{143}$ gave detailed information both on patterns of deviation as related to various classes of survivors and on the treatment accorded the surviving spouse when deviation occurred. The relationship of the survivor class to deviation is illustrated in Table 6.

TABLE 6

Testamentary Deviation from INTEstate Distribution-Chicago Study144

\begin{tabular}{lcc}
\hline Survivor & $\begin{array}{c}\text { Percentage of all } \\
\text { testate that } \\
\text { deviate from } \\
\text { intestate rule } \\
(1)\end{array}$ & $\begin{array}{c}\text { Total no. } \\
\text { of testate } \\
\text { estates } \\
\text { involved } \\
(2)\end{array}$ \\
\hline Spouse and children & 100 & 22 \\
Spouse without children & 83 & 6 \\
Children without spouse & 69 & 35 \\
Neither spouse nor children & & $*$ \\
but brothers or sisters & 89 & $*$ \\
Other relatives survive & 100 & \\
\hline
\end{tabular}

- Not given.

Source: See note 144 .

The first two entries in Table 6 reflect those estates in which a spouse survived the testator. If a decedent was survived by a spouse and children, the Illinois intestacy laws ${ }^{145}$ provided the surviving spouse with only one-third of the estate and the children the remaining twothirds. ${ }^{146}$ As Table 6 indicates, $100 \%$ of the decedents in this category who left a will deviated from the statutory scheme. An examination of the twenty-two wills involved showed that $100 \%$ of these deviating decedents left all of their property to their surviving spouse. ${ }^{147}$

143 Dunham.

144 Column (1) is from Dunham 252, with the exception of the percentage of deviation figure for the category "spouse without children," shown as 83. The Chicago Study gave this percentage figure as 17. Ibid. This was derived by comparing the testate distribution pattern of the estates involved with the intestacy rule regarding personalty. Only one of the wills, or $17 \%$, deviated from the "all to the spouse" rule. On the other hand, it can be seen that all except one, or $83 \%$ deviated from the rule regarding realty. See text accompanying note 144 supra. As the question under investigation here is the extent to which the surviving spouse receives favored treatment, it was felt that the $83 \%$ figure was both statistically accurate and more representative of the point at issue.

Column (2) is derived from Dunham 252-54.

145 It is not clear from the Chicago Study whether the Study data from which table 6 supra was constructed was obtained from the 1953 or 1957 group of estates. As the relevant pattern of intestate distribution was not changed during the period, the information is not critical. It should be noted, however, that the rule for distribution when there is a surviving spouse but no descendants of the deceased was changed by the 1963 Legislature. See note 148 infra.

146 Ill. Rev. Stat. ch. 3, § 11 (Supp. 1965).

147 Dunham 252. 
If a decedent was survived by a spouse but no children, the surviving spouse was entitled to all of the personal estate and one-half of the real estate. ${ }^{148}$ Table 6 indicates that $83 \%$, or five out of the six wills involved, deviated from this scheme. Furthermore, an examination of these six wills showed that five left everything to the surviving spouse. ${ }^{149}$ The one deviant from this was the will of a female testator.

Thus the pattern of distribution when there was a surviving spouse is clear: twenty-seven out of the twenty-eight wills left all to the surviving spouse. The author of the Chicago Study concluded: "The above material indicates that there is no need in practice for a nonbarrable share for the surviving spouse; the surviving spouse is given much more than the statutory one-third in a very high percentage of the wills."150

\section{The Surviving Spouse's Choice: Frequency of Elections Against the Will}

Do surviving spouses agree with the author of the Chicago Study that there is no need in practice for a nonbarrable share? The answer to this question must be sought in an analysis of empirical data on the frequency with which spouses choose the legislative share over that given by the deceased and the economic circumstances in which spouses find themselves when the choices are made. Unfortunately, data on the frequency of spouses' elections are nonexistent. None of the studies of probate court files previously discussed mentioned the point.

In an effort to obtain some information on this point, a survey by questionnaire was made of a sample of Illinois attorneys with estate practices. Details of the survey and the questions asked and answers given can be found in Appendix A. The information presented in the following paragraphs is taken from the data set out in this appendix.

There were 84 attorney-respondents in the sample. Seventy-five listed business addresses. Of these, a third practiced in Chicago, $23 \%$ in other large cities (population more than 60,000 ), $21 \%$ in smaller cities (population between 25,000 and 60,000), and 23\% in towns smaller than 25,000 . Seventy-seven reported on the size of the firm with which they practiced. Eighty-two per cent of this number were sole practitioners or were members of small firms (2 to 6 attorneys).

The respondents reported that in a one year period they participated in a total of 1,513 probate proceedings.

\footnotetext{
148 ILL. REv. Stat. ch. 3, § 11 (1961). This provision was changed in 1963 to give the surviving spouse the entire estate when there are no descendants of the deceased. IIL. REv. STAT., ch. 3, \& 11 (Supp. 1965).

149 Dunham 253.

$150 \mathrm{Id}$, at 255 .
} 
In 717 of these proceedings, or $47 \%$, there was a surviving spouse. There were 19 reported cases in which the spouse chose the share given by the legislature rather than that given by the deceased. This was slightly over $1 \%$ of the total number of proceedings and $2.6 \%$ of the proceedings in which there was a surviving spouse.

The respondents were asked to give their opinion as to why those spouses who elected against the deceased's will did so. Of the nineteen spouses who elected, eight were judged to have been avoiding an attempt to disinherit them. Four others wanted a larger share, but in circumstances in which the size of the testamentary gift was thought not to have been the result of family disharmony. Thus, it can be seen that in the estates in which there was a surviving spouse, there was a felt need for protection from disinheritance, intentional or inadvertent, in somewhat less than $2 \%$ of the cases.

Would the picture change if testators were not faced with the fact of choice-the power of the survivor to force the gift? The respondents were asked how many wills they drew in a year for married individuals and how many of these individuals, in the attorney's judgment, would have made a different provision for the spouse if there was not a nonbarrable share available. Of the 3,441 married testators for whom wills were drafted, the respondents identified 84 testators, or $2.4 \%$, who would have made a different disposition if there had been no threat of the surviving spouse's election.

The strikingly low percentage of elections cannot easily be attributed to an inadequate legislative alternative. Indeed, the Illinois Legislature has given the surviving spouse not one but two alternatives to the deceased's testamentary gift. The spouse (and the choice is available to both husband and wife) may renounce the will and elect to take a statutory share of one-third of the succession estate (both real and personal) if the deceased has a surviving descendant, or one-half if there is no surviving descendant. ${ }^{151} \mathrm{~A}$ second alternative is available; instead of the fractional interest in the succession realty, the spouse can take dower in any realty of which the deceased was seized during the marriage. ${ }^{162}$ This dower alternative is in addition to the fractional share of the succession personalty and can be taken on a parcel-byparcel basis. Thus, the surviving spouse in Illinois can choose onethird to one-half of the personalty and either one-third to one-half in fee or a dower interest in each parcel of real estate, as desired. Few states offer more. 


\section{Summary and Some Observations}

The purpose of this study is to bring together in one place the available data on patterns of wealth transmission at death and to relate these data to the special situation of the surviving spouse. On the basis of empirical data presently available, it is premature to attempt to draw any firm conclusions as to what is sensible social policy regarding the rights of the surviving spouse and the extent to which present legislative attitudes reflect sound policy. By the same token, it would be premature to criticize here the several current proposals for reform. ${ }^{153} \mathrm{But}$ there are some observations that appear warranted.

The vagaries of human behavior are never adequately described in mathematical terms. Nor are solutions to social problems found by careful attention to sums. Dr. Johnson's aphorism is apt: "round numbers are always false." But statistics can reveal patterns and changes in patterns which can be meaningfully related to the judgments involved in the determination of policy regarding the rights of surviving spouses. ${ }^{154}$ This is true even if the effect of the data is to prove what we already believe. To believe is one thing; to act on the basis of unsupported belief is something else.

What policy implications are there in the material developed thus far? It is apparent that the evidence is quite inconclusive on the ques. tion of whether there is a trend toward increasing efforts to disinherit spouses. It is clearer that will substitutes in various forms are extensively used by married individuals, but there is no reason to believe the spouse generally fares poorly in these; indeed, the evidence points to the contrary. Nevertheless, the popularity of will substitutes indicates that this is an area requiring careful scrutiny and warranting specific treatment by the policy maker.

If anything is clear from the available statistics, it is that more and more individuals are disposing of whatever wealth they have by will

153 See authorities cited note 6 supra.

154 These judgments are constantly under review. The Section of Real Property, Probate and Trust Law of the American Bar Association and the National Conference of Commissioners on Uniform State Laws have each within the last several years appointed special committees concerned with model or uniform probate acts. A committee of the Wisconsin Bar Association has been working on a proposed revision of the Wisconsin Probate Law. In 1961 the New York Legislature established a Temporary State Commission on the Modernization, Revision and Simplification of the Law of Estates One of the major areas the Commission has under study is the surviving spouse's right of election. In the spring of 1964 the Illinois State Bar Association polled its membership to determine desired topics for bar meeting programs. Among those at the top of the favored list was "Let's Abolish Dower." The effect of marital rights on marketability of property continues to plague the courts and intrigue the scholars. See e.g., Boyer and Miller, Furthering Title Marketability By Substantive Reforms With Regard To Marital Rights, 18 U. MIAMI L. REv. 561 (1964). 
rather than through intestate succession and that the more wealth they have, the more likely it is that a will will be employed. To the extent wealth holders die intestate, the solution to the surviving spouse's situation is relatively simple. The legislature and the deceased have agreed on what the survivor is to get and there is no conflict of policies. ${ }^{155}$ But when wealth-holders use a will, the stage is set for a potential conflict between society's and the testator's concern for the surviving spouse. This is true whether the issue arises out of a testator's desire to punish the spouse, or simply because he applies a different standard of need.

This leads to the final and perhaps the most significant finding, and here the evidence is strikingly consistent. The married testator on the whole shows little inclination to avenge himself at death for the slights and frictions of marital bliss. If the balance is struck it is not done so publicly. For the total society this has real meaning: the need for a surviving spouse's choice between the deceased spouse's testamentary largess and the legislatively-decreed share is not a need of massive proportions. The machinery designed to satisfy this need need not be massive and insensitive; on the contrary, the dimensions of need are such as to compel the conclusion that the machinery should be keyed to individuation and able to adjust its impact to the circumstances calling it into play. ${ }^{156}$

\section{Addendum: A Note on Data Studies and Some Implications For Future Research}

By far the most useful information and that having the greatest probative value was developed by the two studies of probate court records. ${ }^{157}$ At the same time, these data, for several reasons, were among the most difficult to analyze. The studies did not begin from a common base. While there was an underlying similarity of purpose, the approaches were divergent. This divergence meant that the same types of information were not routinely reported. In some cases it was necessary to reconstruct data in order to make valid comparisons; in other cases meaningful comparisons were impossible.

Some types of information, such as that on spouses' elections, was not reported by either study. Furthermore, the process of analyzing and collating the reported information was made doubly difficult by

155 This assumes, of course, that the intestate share of the surviving spouse is realistic in terms of need and size of estate, a generally unrealistic assumption. See the proposal for reform of the Statute of Distributions in Dunham at 257.

156 See Laufer, Flexible Restraints on Testamentary Freedom-A Report on Decedents Family Maintenance Legislation, 69 HARv. L. REv. 277 (1955); articles cited note 6 supra. 167 Dunham; Ward \& Beuscher. 
the absence in a number of instances of clear identification of the data source. Nevertheless, these two studies yielded a wealth of important information on property transmission practices and established conclusively the value of probate court records as a source of useful empirical data.

What is needed then is a whole series of studies of probate court records. ${ }^{158}$ The patterns of wealth transmission thus developed will not only portray national characteristics, but will reflect the differences resulting from variations in geographical, cultural, and economic conditions. Finally, it must be emphasized that in order to maximize the usefulness of these studies they must be based on a research design that will produce transmissible information. This means that whenever possible the initial data-gathering should include all information available in the records. It would be unfortunate if the time and effort required to make records studies were expended without careful attention being given to the scope of the data collection. Moreover, the presentation of the data in published studies should be made in such a way as to be meaningful to the reader who wishes to make independent analyses of the data. ${ }^{159}$ This is essential if valid comparisons are to be made between different studies.

\section{APPENDIX A}

This appendix presents detailed information on the survey questionnaire discussed in the section entitled The Surviving Spouse's Choice: Frequency of Elections Against the Will, supra p. 712.

The questionnaire was distributed to approximately 400 attorneys attending a short course on estate planning in April, 1964, sponsored by the Institute on Continuing Education of the Illinois Bar. Eightyfour questionnaires were completed and returned. A profile of the respondents is given in the text. ${ }^{100}$ The information for the profile was obtained from preliminary questions asked in an explanatory cover letter included with each questionnaire.

Following is the questionnaire with tabulated total responses indicated. Unless otherwise noted, the data given is based on 84 completed responses to each question.

158 See e.g., Frontiers of Legal Research, 7 AMER. Behavioral ScIENTIST No. 4 (1963). In 1962 both the Section of Real Property, Probate and Trust Law of the American Bar Association and the National Conference of Commissioners on Uniform State Laws appointed special committees to undertake studies looking to promulgation of a model or uniform probate code. It has been reported that in connection with these studies a proposal has been made to conduct field research in the various states on the actual dispositions currently being made by testators.

159 For an excellent illustration of how the social scientist presents his source materials and explains the procedures followed in reaching his conclusions, see Lampman, The Share of Top Wealth-holders in National Wealth (1962).

160 See p. 712 supra. 


\section{Questionnaire on Surviving Spouse's Elections}

Please answer the following questions on the basis of a one year period. Indicate the period you are using (select the period most convenient for you and for which you have available information):

$\square$ Calendar year 1963 [67 respondents checked this item].

$\square 12$ month period ending with the date this questionnaire is filled out, which date is - [16 respondents checked this item].

$\square$ Other (please specify) $[1$ respondent indicated a $71 / 2$ month period from Sept. 1, 1963].

\section{Elections During Probate}

1. Give the number of probate proceedings (wills only, not including intestate proceedings) in which you were professionally involved during the selected year, listed according to the capacities in which you served:

a. personal representative (executor, admin. cta., etc.) ...

b. attorney for the personal representative $\ldots \ldots \ldots \ldots$

c. attorney for surviving spouse .................

172

960

d. attorney for a legatee, devisee or heir, other than a

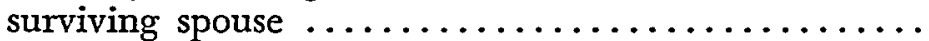

e. attorney for a creditor of the deceased ............

f. other (such as a combination of some of those listed) ..

2. Out of the total number of cases listed in question 1 , indicate how many of the cases involved a decedent who was

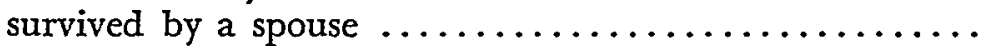

3. Of the number of cases in which a surviving spouse was involved (question 2), indicate in how many cases the spouse actually elected against the deceased's will:

a. by renouncing the will and taking a statutory share in fee (Ill. Prob. Act. $\S 16) \ldots \ldots \ldots \ldots \ldots \ldots \ldots$

b. by making the additional election of dower ( $\$ 18$ ) instead of the statutory share in realty .............

4. If known, indicate as to the cases in which an election was actually made against the will (question 3), whether the primary motivation for making the election was:

a. to increase the share of the estate received by the surviving spouse, the decedent's will making inadequate provision, probably because of poor family relations between them. (give number of cases) ............

b. to increase the share of the estate received by the surviving spouse, the decedent's will making inadequate provision, probably because of change of circumstances, outdated will, etc., and not because of poor family relations. (give number of cases) $\ldots \ldots \ldots \ldots \ldots \ldots$ 
c. to save on taxes for the entire estate (by increasing the marital deduction, etc.) without particular reference to whether it changed the size of the surviving spouse's share vis-à-vis the other legatees. (give number of

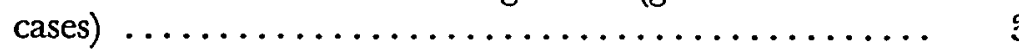

d. other (please specify) $\ldots \ldots \ldots \ldots \ldots \ldots \ldots \ldots \ldots$

\section{Will Drafting}

5. Give the total number of wills you drafted (or participated in the drafting of) during the selected year for testators (male or female) who had a spouse ............... 3,441

6 . Out of the number given in question 5 , how many testators, in your judgment, would have made a different disposition of their property than that finally incorporated in their will if there had not been the threat of the surviving spouse's election. (give number) $\ldots \ldots \ldots \ldots \ldots \ldots$

Of these, how many probably would have substantially or totally disinherited the spouse if they legally could. (give number)

Source identification. In order to have some check on the credibility of the answers received, those questions calling for statistical data (questions 1, 2, 3, and 5) were each followed by a source-identification question:

"The answers I gave to this question were based on (check one): a. $\square$ a survey of my files or records; b. an estimate which I consider to be $-\square$ quite accurate; $\square$ reasonably accurate; $\square$ fairly rough."

The responses to the source-identification questions are presented here in tabular form:

TABLE 7

RESPONSES TO SOURCE-IDENTIFICATION QUESTIONS

\begin{tabular}{lrrrrrrrr}
\hline \multicolumn{1}{c}{ Response } & \multicolumn{2}{c}{ Question 1 } & \multicolumn{2}{c}{ Question 2 } & \multicolumn{2}{c}{ Question 3 } & \multicolumn{2}{c}{ Question 5 } \\
\hline & No. & $\%$ & No. & $\%$ & No. & $\%$ & No. & $\%$ \\
\hline $\begin{array}{l}\text { 1. Response } \\
\text { (a)-survey of files or records }\end{array}$ & 13 & 15.6 & 13 & 17.1 & 12 & 17.9 & 8 & $9.6^{*}$ \\
2. Response & & & & & & & & \\
(b) - estimate considered to be & & & & & & & & \\
$\quad$ a) quite accurate & 26 & 30.9 & 19 & 25.0 & 43 & 64.2 & 21 & 25.3 \\
$\quad$ b) reasonably accurate & 39 & 46.4 & 38 & 50.0 & 12 & 17.9 & 44 & 53.1 \\
$\quad$ c) fairly rough & 6 & 7.1 & 6 & 7.9 & 0 & 0 & 10 & 12.0 \\
Total Responses & 84 & 100.0 & $76^{*}$ & 100.0 & $67 *$ & 100.0 & $83^{*}$ & 100.0 \\
\hline
\end{tabular}

* Note: Some of the respondents who answered the basic questions did not complete the source identification part. 